\title{
流路拡大比の大きい後向きステップ流れの圧力特性と熱伝達特性
}

\author{
五十嵐 武 ${ }^{* 1}$, 佐野 正利 ${ }^{* 2}$
}

\section{Pressure and heat transfer characteristics in a backward-facing step flow with a large expansion ratio}

\author{
Takeshi IGARASHI $^{* 1}$ and Masatoshi SANO ${ }^{* 2}$ \\ ${ }^{* 1}$ Faculty of Mechanical Science and Engineering, Graduate School of Chiba Institute of Technology \\ 2-17-1 Tsudanuma, Narashino-shi, Chiba 275-0016, Japan \\ ${ }^{* 2}$ Department of Mechanical Engineering, Chiba Institute of Technology \\ 2-17-1 Tsudanuma, Narashino-shi, Chiba 275-0016, Japan
}

Received: 28 March 2019; Revised: 8 May 2019; Accepted: 29 May 2019

\begin{abstract}
The effect of the expansion ratio on a backward-facing step flow is investigated experimentally. The expansion ratio $E R$ ranges from 2.0 to 5.0. The Reynolds number based on the mean velocity and the hydraulic diameter of the inlet channel ranges from $2.0 \times 10^{3}$ to $7.0 \times 10^{3}$. This Reynolds number range includes laminar, transition and turbulent flows. The forward flow fraction, the wall static pressure coefficient and the local Nusselt number on the lower wall behind the step are measured. When the position of the reattachment point is nondimensionalized by the step height, it moves to the step side as the $E R$ increases in the laminar region. However, the reattachment length is approximately the same in the turbulent region. For all Reynolds numbers, the pressure loss increases and the Nusselt number decreases as the expansion ratio increases. When the upstream flow transitions from a laminar to a turbulent flow, the pressure loss coefficient increases and the maximum Nusselt number decreases for all expansion ratios. For $E R=2.0$, the position where the maximum Nusselt number appears is downstream of the reattachment point in the laminar flow and is approximately the same in the turbulent flow. In the case of $E R=4.0$ and 5.0, the position is uptream from the reattachment point and is close to a constant value, regardless of the Reynolds number.
\end{abstract}

Keywords : Backward-facing step flow, Expansion ratio, Pressure loss, Reattachment length, Heat transfer

\section{1. 緒言}

熱流体機器の内部流れで発生するはく離・再付着流れは，エネルギー損失に重大な影響を及ぼすとともに機器 の振動・騒音の原因ともなる．はく離・再付着流れの現象解明とその制御は工学的・工業的に重要な課題の一つ である．本論文で解析対象とする後向きステップ流れは，はく離・再付着を伴う典型的な流れであり，はく離点 が摇動しない，はく離・再付着過程に影響を与えるパラメータが少ないといった特徴があることから，はく離・ 再付着流れの現象解明と制御を目的として多くの研究が行われている (Eaton and Johnston, 1981 ; Armaly et al., 1983 ; Vogel and Eaton, 1985 ; Le et al., 1997 ; 本阿弥, 2013). また, 数值計算の精度や乱流モデルの構築・検証と して取り上げられることの多い流れでもある（Kondoh et al., 1993 ; Chen et al., 2006）.

後向きステップ流れの熱流動特性に重大な影響を及ぼすパラメータの代表的なものとしてレイノルズ数と流路 拡大比がある.これまでの研究では, レイノルズ数は層流あるいは乱流に限定され, 流路拡大比は比較的小さい 場合を解析対象としていることが多い。このような状況のもと，過去から現在に至るまでの後向きステップ流れ の流動特性，伝熱特性ならびに制御に関する解説論文が報告されている (Chen et al., 2018)。この論文では流動に 関する実験的研究 40 編，数值計算に関する研究 48 編，伝熱を含む研究 24 編，制御に関する研究 27 編が一覧表

No.19-00137 [DOI:10.1299/transjsme.19-00137], J-STAGE Advance Publication date : 5 June, 2019

${ }^{* 1}$ 学生員, 千葉工業大学大学院 工学研究科（下275-0016 千葉県習志野市津田沼 2-17-1）

*2 正員, フェロー, 千葉工業大学 工学部

E-mail of corresponding author: sano.masatoshi@it-chiba.ac.jp 
としてまとめられ, 解析対象とした後向きステップ流れのレイノルズ数, 流路拡大比, 再付着距離が示されてい る. これらの中で流路拡大比が 2 を超える後向きステップに関する研究は数例のみで, それらも層流あるいは乱 流のみを研究対象としている. 例えば, Tihon et al.は流路拡大比を 1.43，2，2.5，4 と変化させた層流に対して, ステップ下流の流れの構造, 再付着距離に及ぼす流路拡大比の影響を実験と数值計算から調査している（Tihon et al., 2012). しかし, 伝熱を含めて研究を行った例は非常に少なく (Xie and Xi, 2017), 熱伝達特性と圧力分布や再 付着距離との関係についてはほとんど明らかにされていない，また，後向きステップを伴う流路は，片開きの急 拡大流路とみな寸ことができる. 工業的には流路拡大比の大きい管路系が用いられることも多く, 急拡大流路で 発生する圧力損失を明確にすることは非常に重要である. 従来の研究では, 流路拡大比が 2 の乱流場での圧力損 失に及ぼすステップの傾斜の影響（佐野，鈴木，2009）, 同じく流路拡大比が 2 で比較的低レイノルズ数のもとで プラズマアクチュエータによる圧力損失の低減効果（佐野他，2012）を調查した報告などがある。しかし，流路 拡大比の大きい場合の圧力損失に関して系統的な調査を行った研究例は見られない.

本論文では, 後向きステップに至る流れが層流から乱流になるようにレイノルズ数を広範囲に変化させた条件 のもと, 流路拡大比を $2.0 \sim 5.0$ の範囲で 4 種類変更してステップ下流の順流率, 壁面静圧係数, 熱伝達率などの 測定を行う。これらの測定結果にもとづき再付着距離, 圧力損失係数, 最大又セルト数と再付着距離との関係な どを調査し，流路拡大比の大きい後向きステップ流れの圧力特性および熱伝達特性を明らかにする.

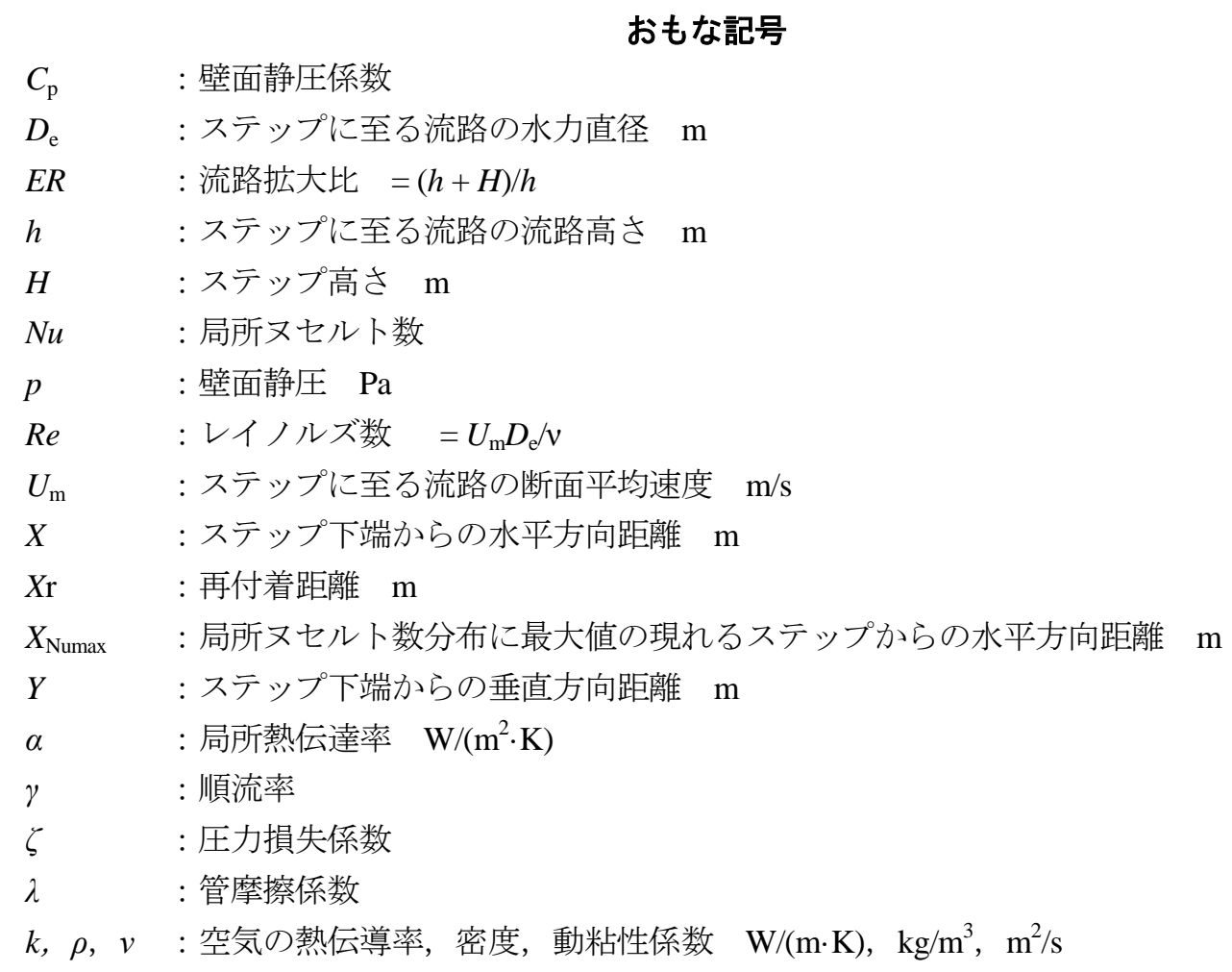

\section{2. 実験装置および実験方法}

本研究で使用する実験装置と流れ場の概要，および座標系を図 1 に示寸．試験流路はアクリル板からなり，ス テップに至る流路は, 流路幅が $250 \mathrm{~mm}$, 流路高さ $h$ が $6.0 \mathrm{~mm}$ の長方形断面形状（アスペクト比 41.7）であり, 十分な流れの二次元性を確保している. 風洞出口からステップまでの長さは $2500 \mathrm{~mm}$ となっており，ステップに 至る流れは発達している. ステップ後方の長さは $1500 \mathrm{~mm}$ である. 座標系はステップからの流れ方向距離を $X$, ステップ下端からの垂直方向距離を $Y$ とする. ステップ高さ $H$ は 4 種類 $(H=6.0,12.0,18.0,24.0 \mathrm{~mm})$ 変化さ せる. したがって, 流路拡大比 $E R$ は 2.0，3.0，4.0，5.0 となる. 流量は送風機に接続されたインバータと送風機 入口に設置された層流形流量計（司測研製：LFE-50B）により設定する.レイノルズ数 Re は $2.0 \times 10^{3} \sim 7.0 \times 10^{3}$ の範囲で変化させる. 


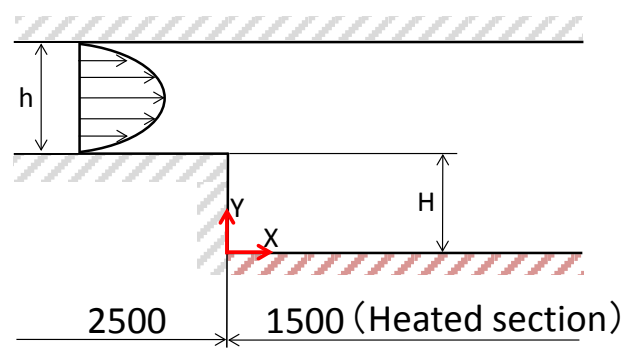

(Unit : $\mathrm{mm}$ )

Fig. 1 Flow configuration and coordinate system. The channel height $h$ is $6.0 \mathrm{~mm}$ and the width is $250 \mathrm{~mm}$ (i.e., the aspect ratio is 41.7). The inlet channel length is $2500 \mathrm{~mm}$, and the flow at the backward-facing step is fully developed. The step height $H$ is varied as 6.0, 12.0, 18.0 and $24.0 \mathrm{~mm}$, so that the expansion ratio $E R$ is 2.0, 3.0, 4.0 and 5.0, respectively. The test plate length behind the step is $1500 \mathrm{~mm}$. Many static pressure holes with a diameter of $0.5 \mathrm{~mm}$ are provided on the test plate. For the heat transfer experiment, the test plate is replaced by a heat transfer plate.

ステップに至る流れの特性を明確にするため, 式（1）にて定義される管摩擦係数 $\lambda$ を測定する.

$$
\lambda=\frac{\Delta p}{\rho U_{\mathrm{m}}^{2} / 2} \frac{D_{\mathrm{e}}}{L_{\mathrm{x}}}
$$

ここで， $\Delta p$ はステップ上流 $600 \mathrm{~mm}$ と $100 \mathrm{~mm}$ の区間長さにおける壁面静圧差， $L_{\mathrm{x}}$ は $\Delta p$ を測定した区間長さで ある.

流れの順流，逆流を判別するためにマイクロフローセンサ（山田他, 2011 ; Koide et al., 2015）を使用し，全時 間のうちで順流の現れる時間割合を表す順流率 $\gamma$ の測定を行う。このセンサはステップに対して下側平板の奥行 き方向の中心位置に流路と平坦になるように設置され，流れ方向の任意の位置に移動できる. マイクロフローセ ンサを使用するにあたり A/D コンバータの分解能は $12 \mathrm{bit}$, サンプリング周波数は $1 \mathrm{kHz}$, データ数は 8192 とし ている.

壁面静圧 $p$ はステップに対して下側平板の奥行き方向の中央位置に直径 $0.5 \mathrm{~mm}$ の静圧孔を設け, 微差圧力計 （GE Druck 製：LP9481）により測定する. 静圧孔は $X=6 \sim 60 \mathrm{~mm}$ の区間では $3 \mathrm{~mm}$ 間隔， $X=60 \sim 180 \mathrm{~mm}$ の区 間では $6 \mathrm{~mm}$ 間隔，それより下流では $12 \mathrm{~mm}$ 間隔で設けられている. 測定された壁面静圧は，式（2）で定義さ れる壁面静圧係数 $C_{p}$ により整理する.

$$
C_{p}=\frac{p-p_{0}}{\rho U_{\mathrm{m}}^{2} / 2}
$$

ここで， $p_{0}$ は基準圧力であり，X/h=1.0での壁面静圧を用いる.

流路拡大部における圧力損失 $\Delta p_{\text {loss }}$ を評価するため, 損失がないとして得られる圧力回復と実験により得られ

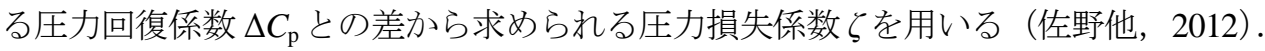

$$
\zeta=\frac{\Delta p_{\text {loss }}}{\rho U_{\mathrm{m}}^{2} / 2}=\left[1-\left(\frac{1}{E R^{2}}\right)\right]-\Delta C_{\mathrm{p}}
$$

熱伝達率の測定にあたっては, ステップに対して下側平板をアクリル板から厚さ $20 \mathrm{~mm}$ のベークライト板に変 更する.この板に厚さ $30 \mu \mathrm{m}$ のステンレス箔を接着し，このステンレス箔を交流電源にて熱流束一定のもとで加 熱する. 局所熱伝達率 $\alpha$ は次式から求める. 


$$
\alpha=\frac{q}{T_{\mathrm{w}}-T_{\mathrm{m}}}
$$

ここで， $T_{\mathrm{w}}$ は局所伝熱面温度， $T_{\mathrm{m}}$ は混合平均温度， $q$ は熱損失を補正した後の熱流束である. 熱損失はベークラ イト板の裹側に取り付けた $\mathrm{T}$ 型熱電対を用いて伝熱面裏側からの熱伝導による損失を評価し, 混合平均温度は流 路入口の空気温度と測定位置までの伝熱量とから計算により求めている.

局所伝熱面温度はステンレス䇴の裏側に取付けた直径 $0.1 \mathrm{~mm}$ の $\mathrm{T}$ 型熱電対により測定する. $\mathrm{T}$ 型熱電対は $X=$ $15 \mathrm{~mm}$ の位置より下流方向に $7.5 \mathrm{~mm}$ 間隔で設置されている. なお, 温度計測システムには, LabVIEW と National Instruments 製の温度計測モジュール SCXI-1102, ターミナルブロック SCXI-1303 を使用している. 局所熱伝達率 は, 式 (5) にて定義される局所ヌセルト数 $N u$ にって整理する. 伝熱実験の詳細は既報に記されている（佐野, 櫻庭, 2001 ; 小川他, 2015)

$$
N u=\frac{\alpha D_{e}}{k}
$$

\section{3. 実験結果および考察}

\section{$3 \cdot 1$ 管摩擦係数}

後向きステップ流れの圧力特性ならびに熱伝達特性の調查にあたっては，ステップに至る流れの特性を明確に しておくことが重要となる. 図 2 にステップ上流の流路で測定された管摩擦係数入をレイノルズ数 Re に対してプ ロットした結果を示す．赤の実線は長方形流路の層流に対する理論式 (日本機械学会編, 1979), 青の実線は乱流 に対するブラジウスの式である. 測定された $\lambda$ は, $R e=4.0 \times 10^{3}$ までは層流の理論式と良好な一致を示し, $R e=5.0$ $\times 10^{3}$ 以上ではブラジウスの式とほぼ一致している.したがって, ステップ上流の流れは $R e \leq 4.0 \times 10^{3}$ では層流, $R e \geq 5.0 \times 10^{3}$ では乱流と判断できる.

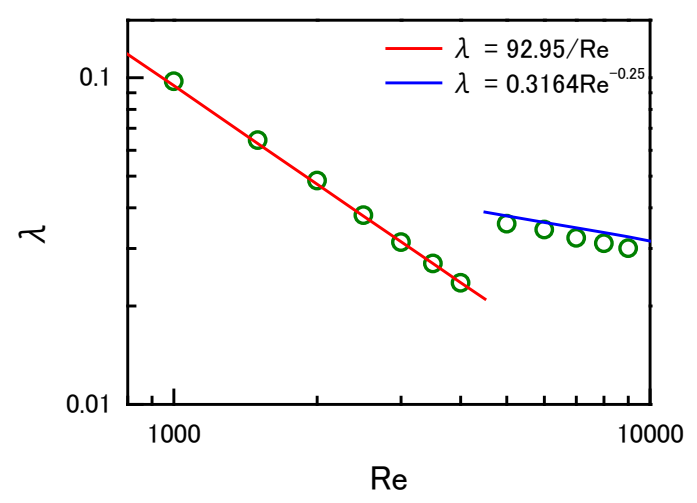

Fig. 2 Pipe friction coefficient $\lambda$ as a function of Reynolds number $R e$. The theoretical curve for the laminar flow and the experimental formula for the turbulent flow appear in red and blue, respectively. The experimental data fit very well along the curves. The Re values correspond to a laminar flow below $4.0 \times 10^{3}$ and a turbulent flow above $5.0 \times 10^{3}$.

\section{$3 \cdot 2$ 順流率}

図 3 にステップ上流の流れが層流である $R e=3.0 \times 10^{3}$ と乱流である $R e=6.0 \times 10^{3}$ を代表例として, 流路拡大比 $E R$ を 4 種類変えて測定された順流率 $\gamma$ の流れ方向分布を示寸. 流れ方向距離 $X$ はステップ高さ $H$ で無次元化さ

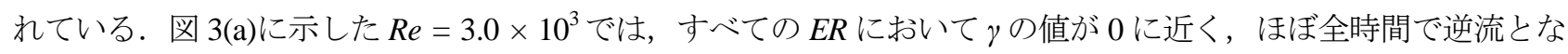
っている状態から $\gamma$ が急増して全時間で順流となる $\gamma=1$ の状態に至るが，急激な増加の発生する位置は $E R$ が大 きくなるにつれてステップ側に移動する. 従来の研究では, $\gamma$ が急増して $\gamma=0.5$ となる位置を再付着点とするこ とが多い（Vogel and Eaton, 1985 ; Chun and Sung, 1998). 図3(a)の結果は，ERの増加にともないステップ高さで無 次元化した再付着距離は短くなることを示寸. ステップに近い $X / H \leq 5$ の分布において, $E R=2.0$ ではステップ 直後で $\gamma \approx 0.15$ となりその下流ですぐに $\gamma=0$ となる. しかし， $E R=4.0,5.0$ のステップ直後での順流率は $\gamma \approx 0.8$ 
と大きく, ステップ後方で順流となっている範囲が $E R=2.0$ に比較して広い. 図 3(b)に示した $R e=6.0 \times 10^{3}$ では, $E R$ の相違によらず $\gamma$ はほぼ一本の曲線上に分布する. したがって, ステップ上流の流れが乱流の場合には, 層流 とは異なり再付着距離は $E R$ の変化の影響をほとんど受けず一定值に近い.

図 4 に流路拡大比は一定としてReの変化が $\gamma$ 分布に及ぼす影響を調査した結果を示す. 図 4(a)は $E R=2.0$, 図 4(b)は $E R=4.0$ であり, Re は 4 条件 $\left(R e=2.0 \times 10^{3}, 4.0 \times 10^{3}, 5.0 \times 10^{3}, 7.0 \times 10^{3}\right)$ について示している. 本実 験条件の中で流路拡大比が最も小さい $E R=2.0$ の層流域 $\left(R e=2.0 \times 10^{3}, 4.0 \times 10^{3}\right)$ での $\gamma=0.5$ となる位置は, $R e$ の大きい方がわずかにステップ方向に移動する程度である. 乱流である $R e=5.0 \times 10^{3}, 7.0 \times 10^{3}$ の $\gamma$ 分布には $R e$ による差がほとんど見られない. $\gamma=0.5$ となる位置は層流に比較して小さく $X / H \approx 7.5$ となる. 流れが層流か ら乱流に遷移寸ると $\gamma$ 分布も大きく変化する. なお, $R e=2.0 \times 10^{3}$ では, $X / H=13$ 付近で $\gamma \approx 1$ となった後に下流 方向に減少して $X / H=17.5$ 付近に極小值が現れ, その下流で再び増加している. $R e=2.0 \times 10^{3}$ では, 他の $R e$ と比 較して再付着点付近の流れがかなり異なる. 流路拡大比の大きい $E R=4.0$ では, $\gamma$ が急増して $\gamma=0.5$ となる位置 はReの相違にかかわらずほとんど変化しない，しかし，ステップに近い $X / H<5$ では， $\gamma$ が大きな值から下流方 向に減少して $\gamma=0$ に至る過程での分布形状が Reによって異なる. 低 Re の方が $\gamma$ の減少が始まる位置が下流側と なり, $\gamma=0$ の状態が継続する領域が狭い. 流路拡大比の大きい場合には, 再付着点付近よりステップに近い領域 にReの影響が現れやすい.

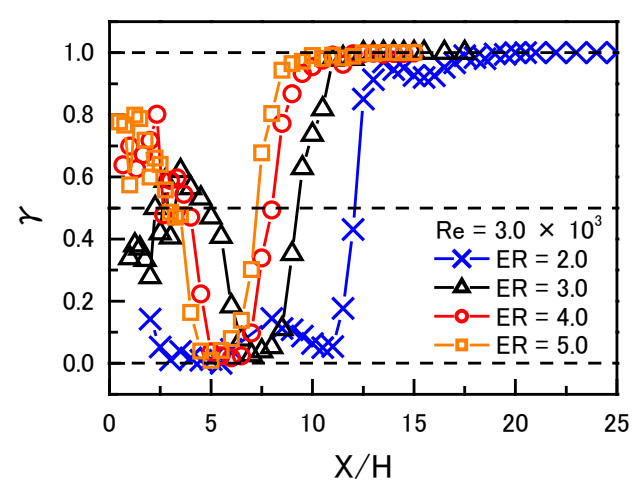

(a) $R e=3.0 \times 10^{3}$

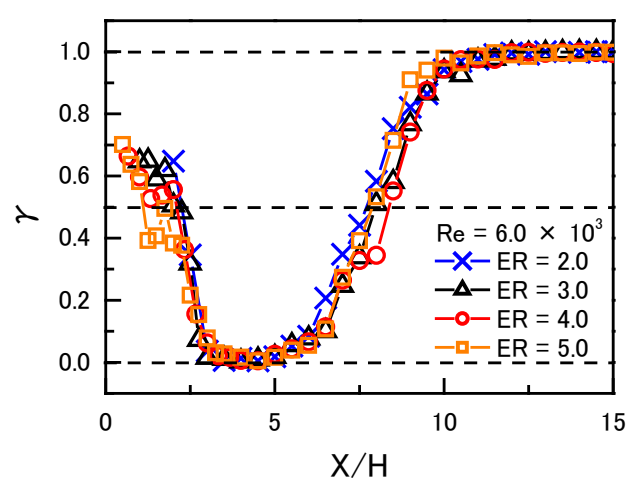

(b) $R e=6.0 \times 10^{3}$

Fig. 3 Forward flow fraction $\gamma$ measured on step side wall. (a) $R e=3.0 \times 10^{3}$ and (b) $R e=6.0 \times 10^{3}$. For $R e=3.0 \times 10^{3}$, the position at which $\gamma$ rapidly rises moves to upstream direction as the expansion ratio $E R$ increases. For $R e=6.0 \times 10^{3}$, the $\gamma$ distributions for all expansion ratios are approximately the same.

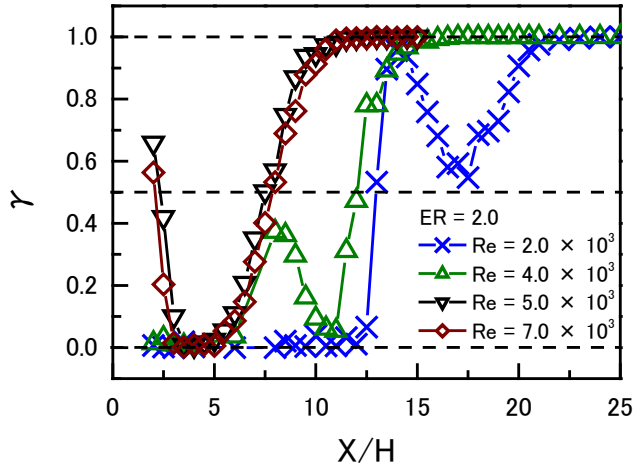

(a) $E R=2.0$

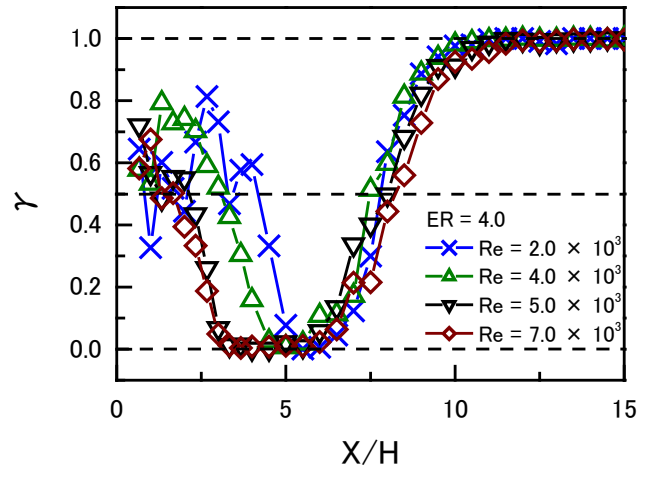

(b) $E R=4.0$

Fig. 4 Forward flow fraction $\gamma$ measured on step side wall. (a) $E R=2.0$ and (b) $E R=4.0$. For $E R=2.0$, the position where $\gamma$ becomes 0.5 moves to upstream direction as Re increases, but the difference between $R e=5.0 \times 10^{3}$ and $7.0 \times 10^{3}$ is slight. At $E R=4.0$, the difference due to $R e$ is small in the region of $X / H>5$, and a difference is observed in the region of $X / H<5$. 


\section{$3 \cdot 3$ 再付着距離}

図 5 に $\gamma=0.5$ となる位置を再付着点として求めた再付着距離 $X \mathrm{r}$ をReに対してプロットした結果を示す.いず れの Reにおいても $E R$ が大きくなるにつれて Xr は増加する. 流路拡大比の増加は再付着距離を長くすることが 確認できる. $E R$ による変化の程度は層流 $\left(R e \leq 4.0 \times 10^{3}\right)$ に比較して乱流 $\left(R e \geq 5.0 \times 10^{3}\right)$ の方が大きい. また, $E R=2.0,3.0$ での $X \mathrm{r}$ は層流より乱流の方が小さいのに対し， $E R=4.0,5.0$ での $\mathrm{Xr}$ は $R e$ の変化にかかわ和らず比較 的一定值に近い.

図 6 に $X \mathrm{r}$ をステップ高さ $H$ で無次元化して Re に対してプロットした結果を示す. ステップ高さで無次元化し た場合には，層流域では図 5 の結果とは反対に $E R$ が増加するにつれて $\mathrm{Xr} / H$ の值は減少し, $E R$ が一定のもとで は Re の増加にともない $X \mathrm{r} / H$ の值は減少する傾向にある. 一方, 乱流域では $E R$ による系統的な変化は見られず, $X \mathrm{r} / H$ の值は Re が大きくなるにつれてわずかに増加し, $\mathrm{Xr} / H=7.5 \sim 8$ となる. 後向きステップ流れに関する従来 の研究では, 再付着距離をステップ高さによって無次元化するのが一般的である. Armaly et al.は ER=1.94 の後 向きステップ流れに対して Re を広範囲に変更して再付着距離の Re 依存性を調査している (Armaly et al., 1983). その結果では, 流れが遷移域に入ると再付着距離は減少して極小值をとり, その後 Re が増加して乱流になると ほぼ一定值 $(X \mathrm{r} / H \approx 8)$ になるとしている. 本研究で流路拡大比がほぼ等しい $E R=2.0$ の結果は, Armaly et al. と 同様の傾向を示す，ステップ高さ $H$ で無次元化した再付着距離は層流域では $E R$ の影響を受けやすいのに対し, 乱流域ではほとんじ受けない，層流と乱流とで $E R$ に対する Re の依存性が異なる． $E R=4.0,5.0$ において Xr/H の值が Re の変化にかかわらず比較的一定值に近いのは，ステップ後方の流れが早期に乱流に遷移するためと考 えられる.

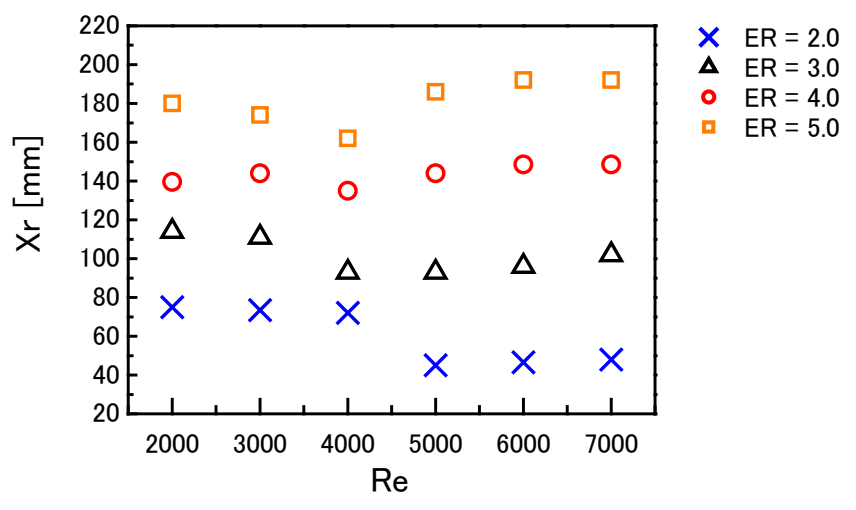

Fig. 5 Reattachment length $X \mathrm{r}$ as function of Reynolds number. The reattachment length increases as the expansion ratio increases. When the flow transitions from laminar to turbulent, $X \mathrm{r}$ decreases at $E R=2.0$, but increases at $E R=5.0$.

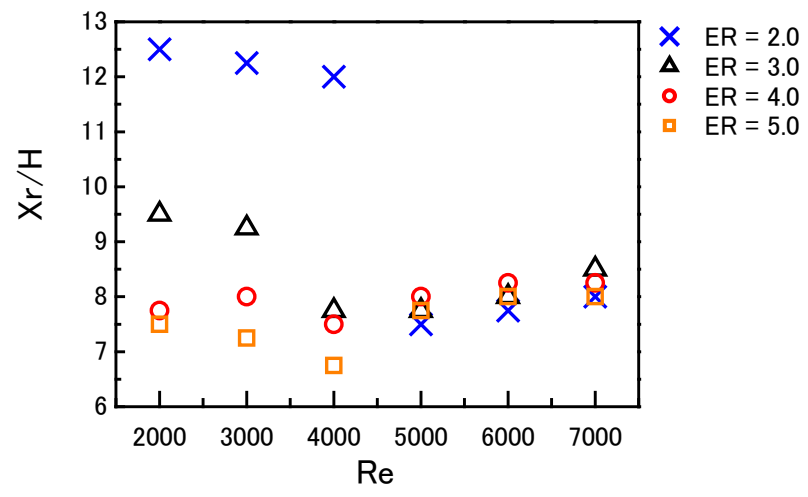

Fig. 6 Reattachment length $X \mathrm{r}$ normalized by step height $H$ as function of Reynolds number. In the laminar region $\left(R e \leq 4.0 \times 10^{3}\right)$, the dimensionless reattachment length $X \mathrm{r} / H$ is the largest at $E R=2.0$ and decreases as the expansion ratio increases. In the turbulent region $\left(R e \geq 5.0 \times 10^{3}\right), X r / H$ exhibits a small difference depending on the expansion ratio and is relatively independent of $R e$. 


\section{$3 \cdot 4$ 圧力特性と伝熱特性}

図 7 に Re は一定として ER の変化が壁面静圧係数 $C_{\mathrm{p}}$ の流れ方向分布に及ぼす影響を調查した結果を示す．測 定条件は図 3 に示した順流率の場合と同じである. 図7(a)の $R e=3.0 \times 10^{3}$ では, $C_{\mathrm{p}}$ が急激に上昇を開始する位置, ならびに最大值が現れる位置は $E R=2.0$ が最も下流となり, $E R$ が大きくなるにつれてこれらの位置は上流側に移 動する. しかし, $E R=4.0$ と $E R=5.0$ との差は小さい. 最大值が現れた位置より下流側での $C_{\mathrm{p}}$ はほぼ直線的に減 少する. $E R=2.0$ では $C_{\mathrm{p}}$ の值が 0 に近い状態が $X / H=10$ 程度まで続くのに対し, $E R=4.0,5.0$ ではステップ直後 から $C_{\mathrm{p}}$ は減少して $X / H=4$ 付近に極小值が現れた後に下流方向に急上昇する. 図 7(b)の $R e=6.0 \times 10^{3}$ では, $E R$ が相違しても $C_{\mathrm{p}}$ の分布形状はあまり変化しない，この傾向は順流率に対寸る測定結果と類似している. また, 流 路の拡大に伴う圧力上昇の程度は, $R e=3.0 \times 10^{3}, 6.0 \times 10^{3}$ ともに $E R$ が大きくなるにつれて減少する.

図 8 に $E R$ は一定のもとで $C_{\mathrm{p}}$ 分布に及ぼす $R e$ の影響を調査した結果を示す. 図 8(a)の $E R=2.0$ では, $X / H \leq 10$ のステップに近い領域での $C_{\mathrm{p}}$ 分布は $R e=2.0 \times 10^{3}$ と $R e=4.0 \times 10^{3}$ とでほとんど差がない. しかし, $R e=2.0 \times 10^{3}$ では $X / H=10$ 付近から急上昇する $C_{\mathrm{p}}$ の傾きが， $X / H=15$ 付近を中心として緩やかとなる. これは図 4 に示した $\gamma$ 分布において, $\gamma$ が小さくなる領域と一致している. $R e=5.0 \times 10^{3}, 7.0 \times 10^{3}$ では, $X / H=3$ 付近から $C_{\mathrm{p}}$ は急上昇 するが $R e=5.0 \times 10^{3}$ の方がわずかに圧力上昇の程度が大きい. ステップ上流の流れが層流から乱流に遷移すると $C_{\mathrm{p}}$ 分布も大きく変化する. 図 8(b)に示した $E R=4.0$ のステップ近傍では, $E R=2.0$ の $R e=2.0 \times 10^{3}, 4.0 \times 10^{3}$ で は $X / H=10$ 付近まで $C_{\mathrm{p}}$ 值がほぼ 0 で一定值を示寸領域が存在するのに対し，いずれの Reにおいても $C_{\mathrm{p}}$ がほぼ 一定值を示す領域は見られず， $C_{\mathrm{p}}$ は下流方向に減少した後に上昇する.

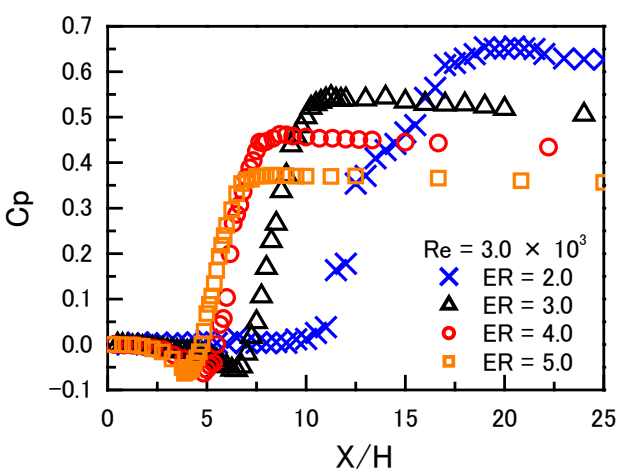

(a) $\operatorname{Re}=3.0 \times 10^{3}$

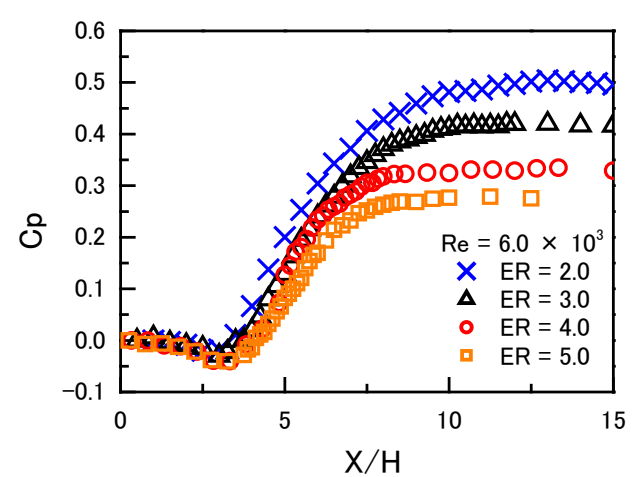

(b) $R e=6.0 \times 10^{3}$

Fig. 7 Wall static pressure coefficient $C_{\mathrm{p}}$ distributions measured on step side plate. (a) $R e=3.0 \times 10^{3}$ and (b) $R e=6.0 \times 10^{3}$. For $R e$ $=3.0 \times 10^{3}$, the position at which $C_{\mathrm{p}}$ rapidly rises moves to the step side as the expansion ratio increases as well as the forward flow fraction distributions. The pressure recovery decreases as the expansion ratio increases. For $R e=6.0 \times 10^{3}, C_{\mathrm{p}}$ distributions near the step are almost the same for all expansion ratios.

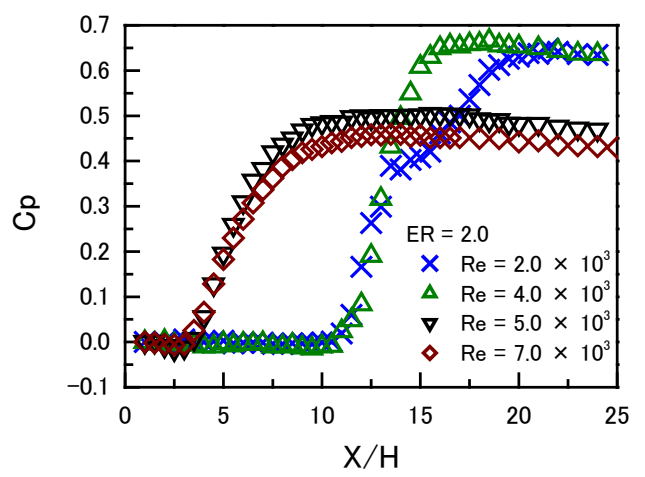

(a) $E R=2.0$

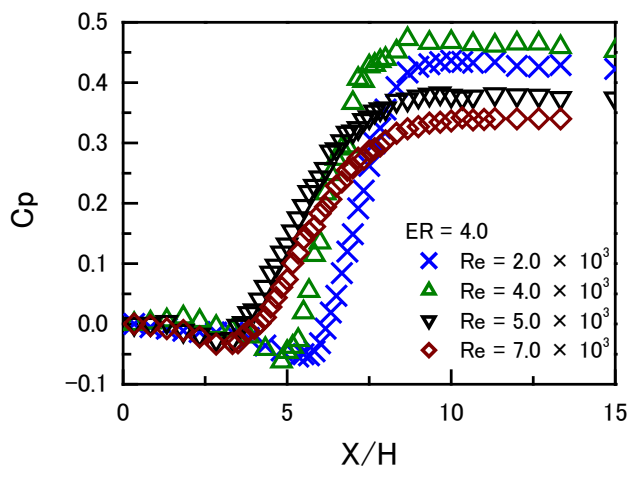

(b) $E R=4.0$

Fig. 8 Wall static pressure coefficient distributions $C_{\mathrm{p}}$ measured on step side plate. (a) $E R=2.0$ and (b) $E R=4.0$. For $E R=2.0$, the $C_{\mathrm{p}}$ distributions vary greatly between laminar flow and turbulent flow. In turbulent flow, the position where $C_{\mathrm{p}}$ rapidly rises moves to the step side compared to laminar flow. At $E R=4.0$, the difference due to $R e$ is small. 
図 9 に壁面静圧係数の最大值 $C_{\mathrm{pmax}}$ を Re に対してプロットした結果を示す. 層流域（Re $\left.\leq 4.0 \times 10^{3}\right)$ での $C_{\mathrm{pmax}}$ は, $E R=2.0$ では約 $0.65, E R=5.0$ では約 0.36 となり $E R$ が大きくなるにつれて圧力上昇の程度は小さくなる. い ずれの $E R$ においてもレイノルズ数が $R e=4.0 \times 10^{3}$ から $R e=5.0 \times 10^{3}$ に増加して流れが層流から乱流に遷移寸る と $C_{\text {pmax }}$ は急激に減少する. 乱流域 $\left(R e \geq 5.0 \times 10^{3}\right)$ での $C_{\text {pmax }}$ は, 寸べての $E R$ において $R e$ の増加につれて減少 する傾向にある.

図 10 に圧力損失係数 $\zeta$ を Re に対してプロットした結果を示す. $C_{\mathrm{pmax}}$ の結果とは反対にいずれの Reにおいて も $E R$ が大きいほど圧力損失は増加する. また, 同一の $E R$ で $\zeta$ の值を比較すると $R e \leq 4.0 \times 10^{3}$ より $R e \geq 5.0 \times 10^{3}$ の方が大きく, ステップ上流の流れが層流から乱流に遷移すると圧力損失は増加する. $R e \leq 4.0 \times 10^{3}$ での $\zeta$ は $E R$ $=2.0$ では 0.1 以下であるが, $E R=5.0$ では 0.6 程度となって大きな圧力損失が発生する. $R e \geq 5.0 \times 10^{3}$ での $\zeta$ は $E R=2.0$ では $0.25 \sim 0.3, E R=5.0$ では約 0.7 である. なお, 遷移による $\zeta$ の増加の程度は $E R$ の小さい方が大きい. これは図 8 に示したように $E R$ の小さい場合には遷移によって $C_{\mathrm{p}}$ 分布が大きく変化するのに対し，ER の大きい 場合にはその変化が小さいことに対応する.

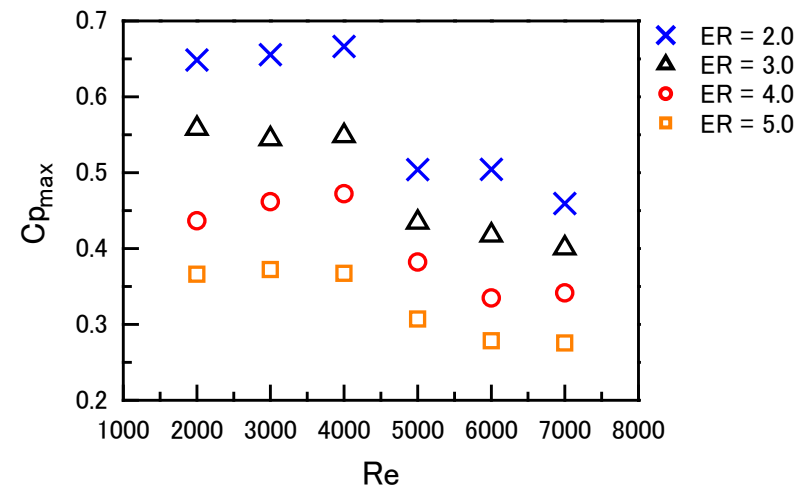

Fig. 9 Maximum wall static pressure coefficient $C_{\text {pmax }}$ as function of Reynolds number. For all expansion ratios, $C_{\text {pmax }}$ is larger in laminar flow compared to turbulent flow. As the expansion ratio increases, $C_{\mathrm{pmax}}$ decreases.

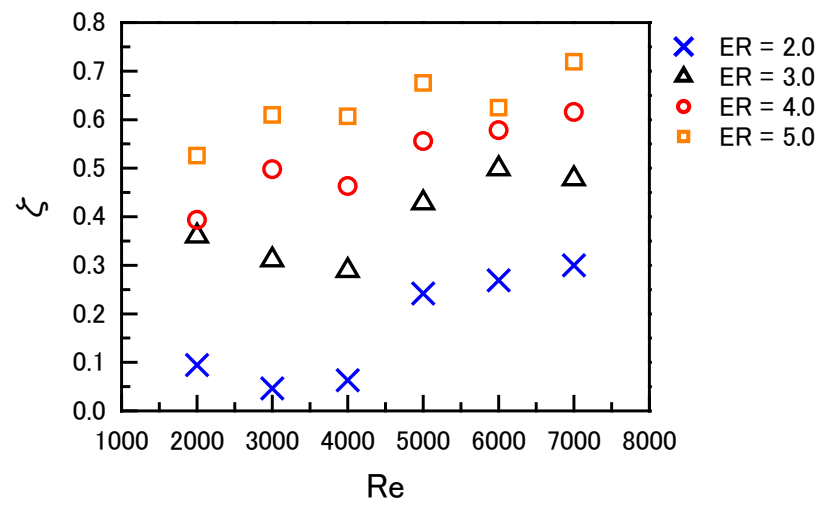

Fig. 10 Pressure loss coefficient $\zeta$ as function of Reynolds number. As the expansion ratio increases, the pressure loss coefficient increases. When the flow at the step transitions from laminar flow to turbulent flow, the pressure loss coefficient increases abruptly for all expansion ratios.

図 3, 7 と同一の条件のもとで測定された局所ヌセルト数 $N u$ の流れ方向分布を図 11 に示寸. 図 $11(\mathrm{a})$ の $R e=3.0$ $\times 10^{3}$ では, $E R$ が大きくなるにつれて $N u$ 分布にピークの現れる位置はステップ側に移動し, ピークの值は小さく なる. Nu が減少する要因としては ER の増大によるステップ後方での断面平均速度の減少があげられる. 図 11(b) の $R e=6.0 \times 10^{3}$ では, $E R$ の相違にかかわらず $N u$ 分布にピークの現れる位置は $X / H=6 \sim 8$ となり, ピークが現 れた位置より下流側での $N u$ は緩やかに減少寸る. $N u$ の分布形状は $E R=2.0$ から $E R=3.0$ の間の変化が大きく, $E R=4.0$ と $E R=5.0$ との差は非常に小さい. 
図 12 に $E R$ は一定のもとで $N u$ 分布に及ぼす $R e$ の影響を調查した結果を示す. 図 $12(\mathrm{a})$ の $E R=2.0$ において, $R e=2.0 \times 10^{3}$ では明瞭なピークは見られず, $X / H=15 \sim 20$ での $N u$ は比較的一定值に近い. 一方, $R e \geq 4.0 \times 10^{3}$ では明瞭なピークが見られる. $R e=2.0 \times 10^{3}$ では, 他の Re とは異なる流動状態となっていることが示唆される. $R e=5.0 \times 10^{3}, 7.0 \times 10^{3}$ においては, ピークの值に差はあるもののピークの現れる位置に変化はなく, 分布形状も 比較的類似している. 流れが乱流の場合には $\gamma$ 分布, $C_{\mathrm{p}}$ 分布, $N u$ 分布ともに Re に対する依存性が弱まる. 図 12(b) の $E R=4.0$ では, Reが相違してもピーク位置にはほとんど変化は見られないが，ステップ直後の $N u$ が下流方向 に減少して極小值をとった後に $N u$ が増加を開始する位置は Reが大きくなるにつれてステップ側に移動する. $N u$ 分布においても流路拡大比の大きい場合には, 再付着点付近よりステップに近い領域にRe の影響が現れや寸い. この傾向は $\gamma$ 分布に対する測定結果と同じである.

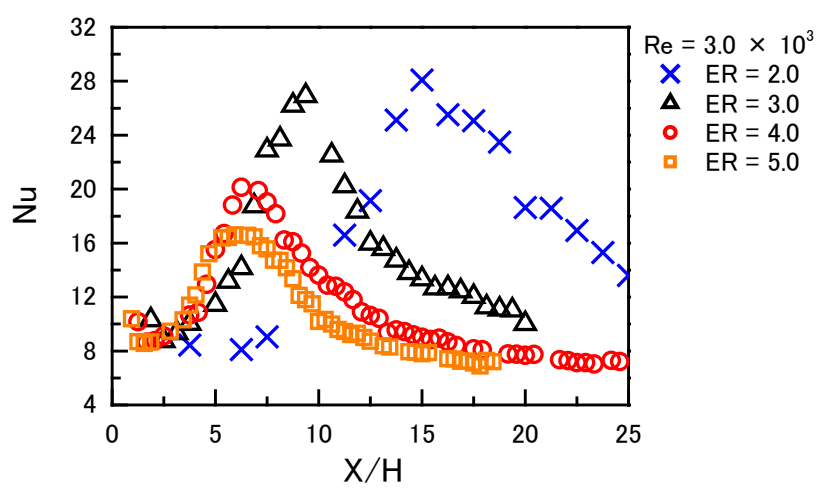

(a) $R e=3.0 \times 10^{3}$

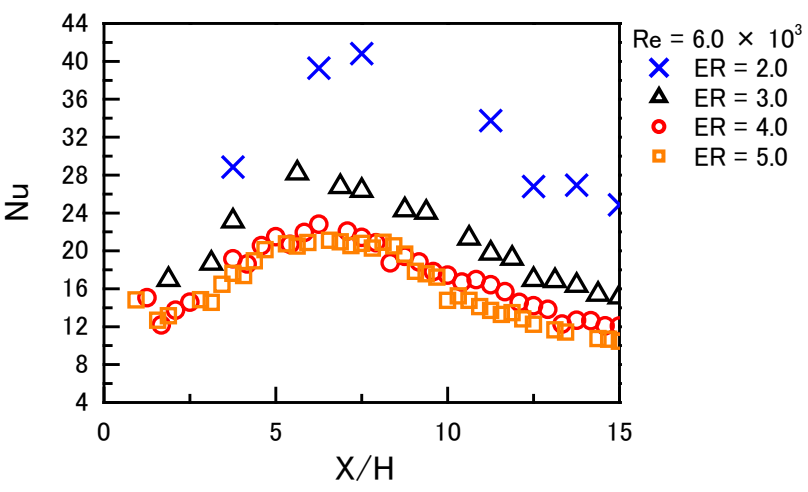

(b) $R e=6.0 \times 10^{3}$

Fig. 11 Local Nusselt number $N u$ distributions measured on step side wall. (a) $R e=3.0 \times 10^{3}$ and (b) $R e=6.0 \times 10^{3}$. For $R e=3.0$ $\times 10^{3}$, as the expansion ratio increases, the position where the maximum value appears in the $\mathrm{Nu}$ distribution moves to the step side and the maximum value decreases. For $R e=6.0 \times 10^{3}$, the distance from the step in which the maximum value appears is almost the same irrespective of the expansion ratio, and the distribution of $E R=4.0$ is similar to that obtained for $E R=5.0$.

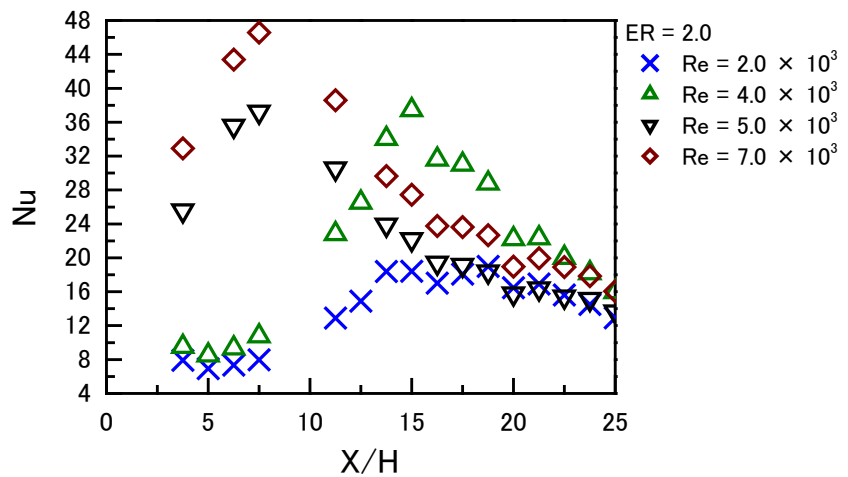

(a) $E R=2.0$

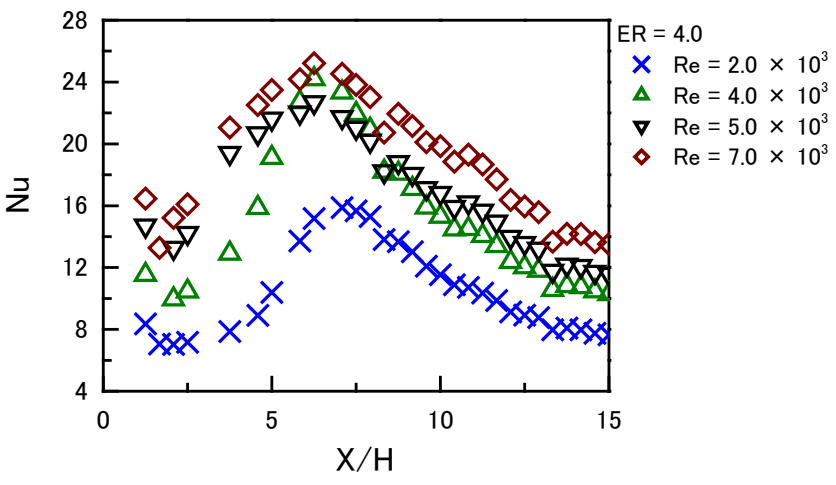

(b) $E R=4.0$

Fig. 12 Local Nusselt number $N u$ distributions measured on step side wall. (a) $E R=2.0$ and (b) $E R=4.0$. As $R e$ increases, $N u$ also increases. At $E R=2.0$, the position where the maximum value appears in the $N u$ distribution moves to the step side in turbulent flow as compared with laminar flow. For $E R=4.0$, its position is nearly independent of $R e$.

図 13 に $N u$ 分布における最大又セルト数 $N u_{\max }$ をRe に対してプロットした結果を示す. $E R$ が一定のもとでは, $N u_{\max }$ はRe が増加するにつれて大きくなる傾向にある. しかし, $R e=4.0 \times 10^{3}$ から $R e=5.0 \times 10^{3}$ の遷移域で $N u_{\max }$ は減少寸る. 遷移域での $N u_{\max }$ の減少は, この領域で見られた $C_{\mathrm{pmax}}$ の減少や $\zeta$ の増加にも関係していると考えら 
れる.これらの変化の要因を明らかにするためには, 速度場の詳細な測定を行う必要がある. Re が一定のもと で $N u_{\max }$ を比較すると図 11,12 の結果から予想されるように $E R$ の大きい方が $N u_{\max }$ は小さい. しかし, Re $\geq 6.0 \times$ $10^{3}$ での $E R=4.0$ と $E R=5.0$ との差はわずかである.

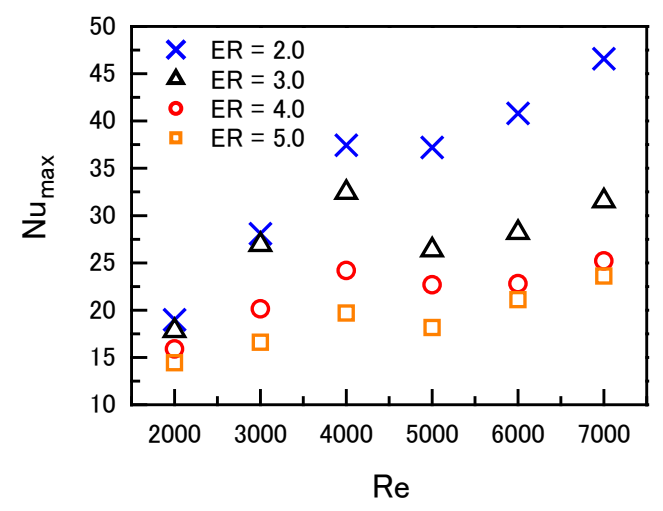

Fig. 13 Maximum Nusselt number $N u_{\max }$ as function of Reynolds number. $N u_{\max }$ increases as $R e$ increases for all expansion ratios, excluding the range from $R e=4.0 \times 10^{3}$ to $R e=5.0 \times 10^{3} . N u_{\max }$ is the largest at $E R=2.0$ and decreases as the expansion ratio increases.

図 14 に $R=2.0 \times 10^{3}$ で測定された順流率 $\gamma$, 壁面静圧係数 $C_{p}$, 局所又セルト数 $N u$ の流れ方向分布をまとめて 示す. 図 $14(\mathrm{a})$ は $E R=2.0$, 図 14(b)は $E R=5.0$ の結果である. 図中には $\gamma=0.5$ となる再付着点位置が赤の破線に て示されている. $E R=2.0$ では，ステップ直後から再付着点の直前まで逆流状態（ $\gamma=0 ）$ が継続し， $C_{p}$ の值は 0 で，Nu の值は小さい. その後 $\gamma$ は急増して再付着点直後ですぐに順流となる. その下流の $X / H=13$ 付近から $\gamma$ は減少して $X / H=17.5$ 付近で極小值をとり, その後再び増加して $X / H=20$ 付近で $\gamma=1$ となる. この領域での $C_{p}$ は急増した後に $\gamma$ が減少を開始する付近から増加の程度が緩慢となり，Nu は再付着点近傍での高い值が $X / H=20$ 付近まで続く. $E R=5.0$ では, ステップ直後の $\gamma$ の值は大きく, 下流方向に減少して $X / H=3$ 付近で $\gamma=0.5, X / H=$ 5 付近で $\gamma=0$ となった後に増加して $X / H=7$ 付近で再び $\gamma=0.5$ となる. ステップ後方の流れの構造としてコーナ 一渦と再循環領域の存在が知られている（Le et al., 1997 ; Tihon et al., 2001）.コーナー渦はステップ直後の下側平 板付近に現れる反時計周りの渦であり，この渦の存在により壁面近くの流れは順流となる. Tihon et al.はコーナー 渦と再循環領域のサイズの指標としてステップ直後の $\gamma$ の大きな值から減少して $\gamma=0.5$ となる位置までをコーナ 一渦の領域，この位置から $\gamma$ が減少して 0 となった後に再び増加して $\gamma=0.5$ となる位置までを再循環領域，それ より下流を再発達領域と分類している. Tihon et al.の分類によれば, $E R=2.0$ ではコーナ一渦のサイズは非常に小 さく, 流路拡大比の大きい $E R=5.0$ ではコーナー渦のサイズが大きく, 再循環領域が狭いことになる. $E R=5.0$ では，コーナー渦の影響によりステップ直後の $N u$ は $X / H=2 \sim 3$ 付近での $N u$ より大くなり, $C_{p}$ は下流方向に 緩やかに減少するものと考えられる. $\gamma=0$ となる位置よりわずかに上流位置から $C_{p}$ は急上昇し, 再付着点より わずかに下流位置に最大值が現れる. 一方, $N u$ は再付着点より上流側にピークが現れる. ステップ上流の流れが 層流の場合には, ERの相違によってステップ後方の熱流動特性は大きく変化する.

困 15 に $R e=7.0 \times 10^{3}$ での $\gamma, C_{p}, N u$ の流れ方向分布を示す. 図 15(a)は $E R=2.0$, 図 15(b)は $E R=5.0$ の結果で ある. $E R=2.0$ では, $R e=2.0 \times 10^{3}$ の結果とは異なりステップ直後で $\gamma>0.5$ となり，再付着した下流で $\gamma=1$ とな った後はその状態が下流方向に持続する. $C_{p}$ 分布は $X / H=3$ 付近から単調に増加して $\gamma=1$ となる付近に最大值が 現れる. $N u$ 分布にピークの現れる位置は，再付着点とほぼ一致する. $E R=5.0$ では，ステップ直後での $\gamma$ と $N u$ は $X / H=2$ 付近での值より大きく, $C_{p}$ 分布に最大值の現れる位置は再付着点よりわずかに下流になり, Nu 分布の ピーク位置は再付着点より上流にあることなど, $R e=2.0 \times 10^{3}$ で得られた結果とほとんど変化がない. ERが大き い場合の $C_{p}$ 分布, $N u$ 分布はステップに至る流れが層流か乱流かによってあまり変わらず Re の依存性が弱まる. この結果は，ステップ下流の流れが早期に乱流に遷移するためと考えられる. 


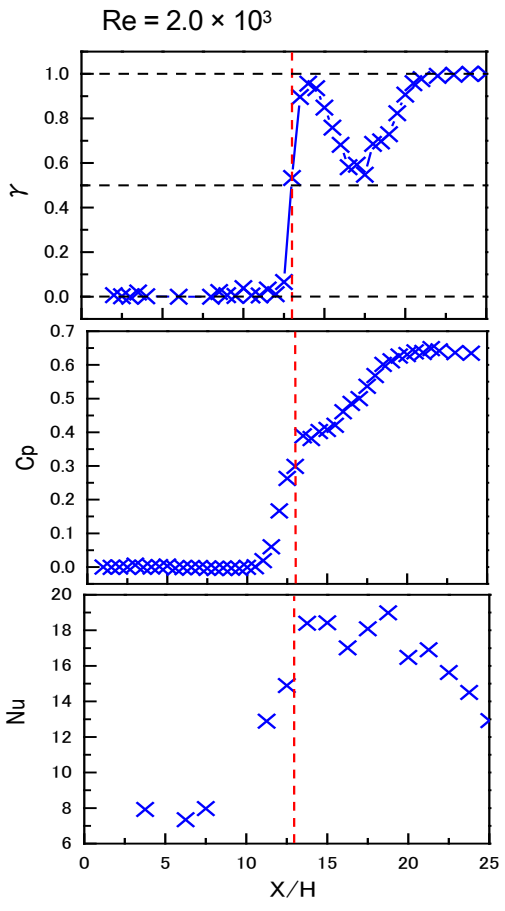

(a) $E R=2.0$

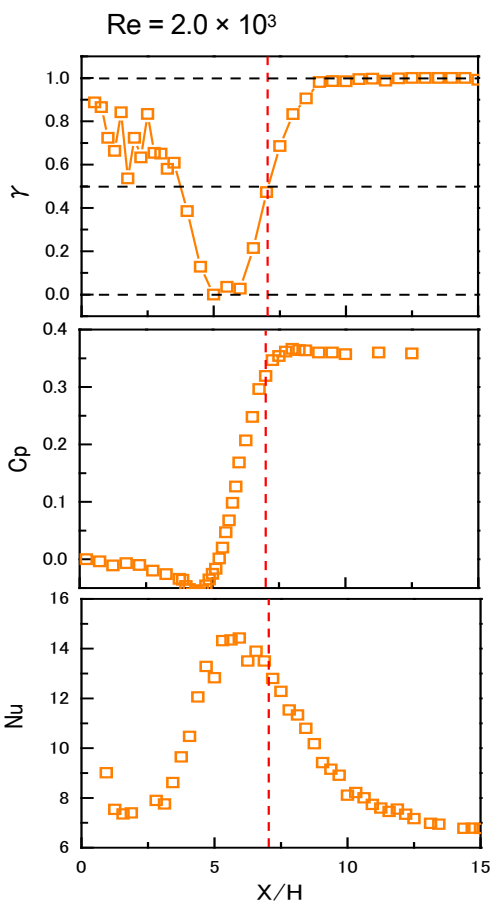

(b) $E R=5.0$

Fig. 14 Forward flow fraction $\gamma$, wall static pressure coefficient $C_{\mathrm{p}}$ and local Nusselt number $\mathrm{Nu}$ for $R e=2.0 \times 10^{3}$. The dashed (red) line indicates the location which becomes $\gamma=0.5$. (a) $E R=2.0$ and (b) $E R=5.0$. For $E R=2.0$, as compared with the location which becomes $\gamma=0.5$ (reattachment position), the streamwise location of $N u_{\max }$ is downstream. For $E R=5.0$, the streamwise location of $C_{\text {pmax }}$ is slightly downstream, and that of $N u_{\max }$ is slightly upstream, as compared with the reattachment position.

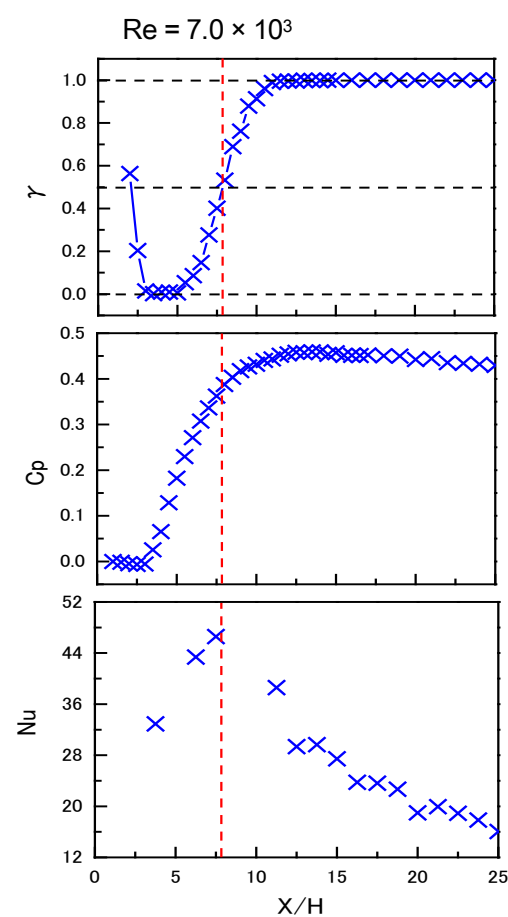

(a) $E R=2.0$

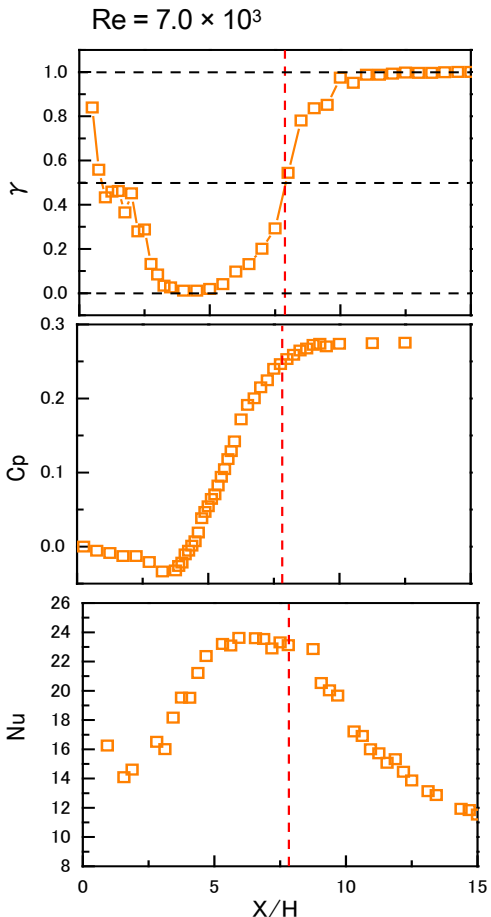

(b) $E R=5.0$

Fig. 15 Forward flow fraction $\gamma$, wall static pressure coefficient $C_{\mathrm{p}}$ and local Nusselt number $N u$ for $R e=7.0 \times 10^{3}$. (a) $E R=2.0$ and (b) $E R=5.0$. For $E R=2.0$, the streamwise location of $N u_{\max }$ is approximately the same at the reattachment position. For $E R$ $=5.0$, the streamwise location of $C_{\text {pmax }}$ is slightly downstream, and that of $N u_{\max }$ is slightly upstream, as compared with the reattachment position. 
図 16 に $E R$ ごとに最大ヌセルト数が現れた流れ方向距離 $X_{\mathrm{Numax}}$, ならびに $\gamma$ 分布より求めた再付着長さ $X \mathrm{r}$ をス テップ高さ $H$ で無次元化し， Re に対してプロットした結果を示す. $E R=2.0$ では，流れが層流域での $X \mathrm{r} / H$ は約 12 に対し $X_{\mathrm{Numax}} / H$ は約 15 であり, 再付着点に対して $X_{\mathrm{Numax}}$ はかなり下流となる. Re が低い層流の場合にはステ ップと対向する上壁面側に反時計周りの渦が形成されることが報告されている (Armaly et al., 1983;山田他, 2011). その渦の影響により再付着点より下流のステップ側壁面近傍の流れが加速され, 再付着点より下流の位置に $N u_{\max }$ が現れるものと考えられる. $R e \geq 5.0 \times 10^{3}$ では， $X_{\mathrm{Numax}} / H$ と $X \mathrm{r} / H$ はほぼ一致する. ステップ上流の流れが乱流で $E R=2$ の熱流動特性を調査した研究では, $N u_{\max }$ は乱れ強度が最も強くなる付近に現れ, その位置は再付着点とほ ぼ一致することが報告されている（佐野，鈴木，2009）。しかしながら，後向きステップを有する乱流境界層の再 付着領域の熱伝達に関する研究（河村他, 1988), 円管内オリフィス下流の再付着位置と熱伝達との関係を調査し た研究（椎原他，2016）では，熱伝達率に最大值の現れる位置は，再付着点の上流となることが明らかにされて いる. また, $E R=3.0$ では, 層流域での $X_{\mathrm{Numax}} / H$ と $X \mathrm{r} / H$ とはほぼ同じ值となり, 乱流域では $X \mathrm{r} / H$ の方が大きい.

$E R=4.0,5.0$ では，すべての Reにおいて $X \mathrm{r} / H>X_{\mathrm{Numax}} / H$ となり，かつRe依存性もあまり見られない. このよう な変化の要因については, ステップ後方の速度分布, 乱れ分布, 速度変動のスペクトルなどの測定を行い, 流路 拡大比が大きい後向きステップの流動特性，ならびに流動と熱伝達との関係を調査する必要がある.

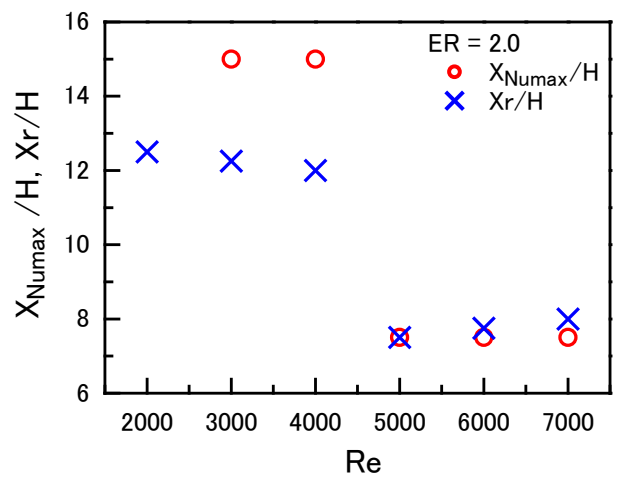

(a) $E R=2.0$

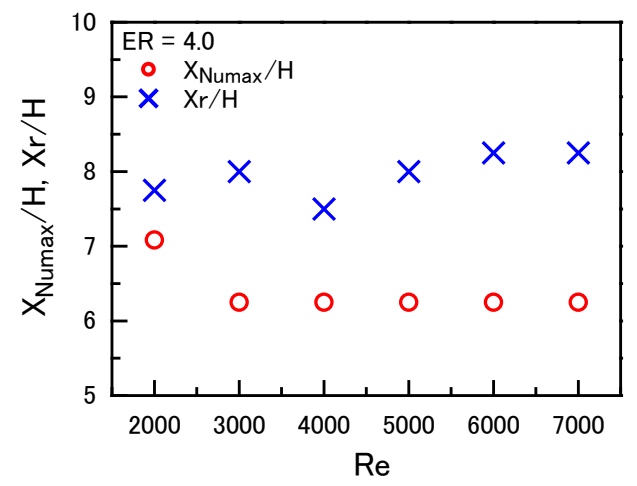

(c) $E R=4.0$

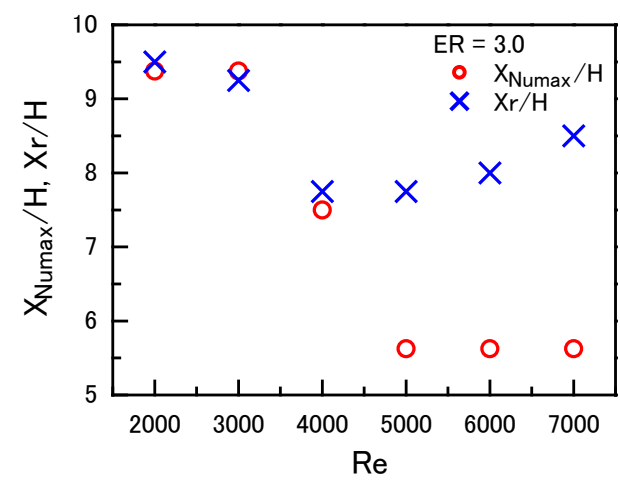

(b) $E R=3.0$

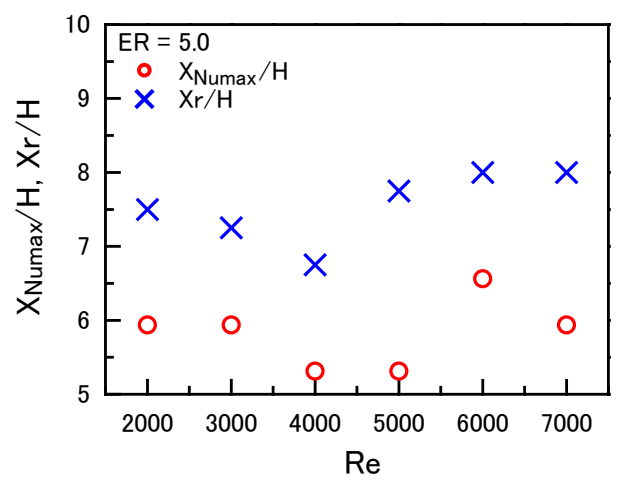

(d) $E R=5.0$

Fig. 16 Streamwise location of maximum Nusselt number $X_{\text {Numax }} / H$ and reattachment length $X \mathrm{r} / H$ as function of Reynolds number. (a) $E R=2.0$, (b) $E R=3.0$, (c) $E R=4.0$ and (d) $E R=5.0 . X_{\text {Numax }} / H$ in laminar flow $\left(R e \leq 4.0 \times 10^{3}\right)$ is downstream at $E R=$ 2.0 and upstream at $E R=4.0$ and 5.0, as compared with the reattachment length. $X_{\text {Numax }} / H$ in turbulent flow $\left(R e \geq 5.0 \times 10^{3}\right)$ is approximately the same at $E R=2.0$, and is upstream at $E R \geq 3$, as compared with the reattachment length.

\section{4. 結 論}

本研究では, 流路拡大比の大きい後向きステップ流れの圧力特性と熱伝達特性に及ぼす流路拡大比の影響を実 験的に調査した. 本研究によって得られた主要な結論を以下に示す. 
(1) 再付着距離 $X \mathrm{r}$ は流路拡大比 $E R$ が大きくなるにつれて長くなる. しかし, $X \mathrm{r}$ をステップ高さ $H$ で無次元化し た $X \mathrm{r} / H$ の值は，ステップ上流の流れが層流の場合には流路拡大比 $E R$ が大きくなるにつれて小さくなり，乱 流の場合には $E R$ に関係なくほぼ一定值に近い. 遷移域での $X \mathrm{r} / H$ は, $E R=2.0$ では急激に減少するが, $E R=4.0$, 5.0 ではその変化は小さい.

(2) $E R$ が大きくなるにつれて圧力損失係数 $\zeta$ は増加し, 局所ヌセルト数 $N u$ の最大值 $N u_{\max }$ は減少する. また, すべてのERにおいてステップ上流の流れが層流から乱流に遷移するととは急増する. その変化の程度は $E R$ = 2.0 で大きく, $E R=4.0,5.0$ では小さい. $N u_{\max }$ は Re が大きくなるにつれて増加する傾向にあるが，遷移域 では減少する.

(3) 最大ヌセルト数が現れるステップからの距離は, $E R=2.0$ の層流域では再付着距離より長く, 乱流域ではほ ぼ等しい. $E R=4.0,5.0$ ではすべてのReにおいて再付着距離の方が長い.

(4) 流れが層流 $\left(R e=2.0 \times 10^{3}\right)$ の $E R=2.0$ では順流率が 0 となる領域が再付着点近傍まで続き，その領域で $C_{p}$ は一定となり，Nu は小さな值となる. $E R=5.0$ ではコーナ一渦のサイズが大きく，ステップ直後の $N u$ は大 きな值となり， $C_{p}$ は下流方向に緩やかに減少する. 流れが乱流 $\left(R e=7.0 \times 10^{3}\right)$ になると $E R$ が変化しても $C_{p}$ 分布, $\mathrm{Nu}$ 分布に大きな差はない.

(5) 流路拡大比が大きい $E R=4.0,5.0$ の再付着距離, $C_{p}$ 分布, $N u$ 分布は, ステップに至る流れが層流か乱流か によってあまり変わらず, 圧力特性, 熱伝達特性に及ぼす $R e$ の依存性が弱まる.

\section{文献}

Armaly, B. F., Durst, F., Pereira, J. C. F. and Schonung, B., Experimental and theoretical investigation of backward-facing step flow, Journal of Fluid Mechanics, Vol. 127 (1983), pp. 473-496.

Chen, L., Asai, K., Nonomura, T., Xi, G. and Liu, T., A review of backward-facing step (BFS) flow mechanics, heat transfer and control, Thermal Science and Engineering Progress, Vol. 6 (2018), pp. 194-216.

Chen, Y. T., Nie, J. H., Armaly, B. F. and Hsieh, H. T., Turbulent separated convection flow adjacent to backward-facing step - effects of step height, International Journal of Heat and Mass Transfer, Vol. 49 (2006), pp. 3670-3680.

Chun, K. B. and Sung, H. J., Visualization of a locally-forced separated flow over a backward-facing step, Experiments in Fluids, Vol. 25 (1998), pp.133-142.

Eaton, J. K. and Johnston, J. P., A review of research on subsonic turbulent flow reattachment, AIAA Journal, Vol. 19. No. 9 (1981), pp.1093-1099.

本阿弥眞治, アクチュエータ空力特性の向上に基づく流れの制御技術の新たな展開, 日本機械学会論文集 B編, Vol. 79, No. 808 (2013), pp. 2670-2678.

河村隆雄，田中誠司，熊田雅弥，馬淵幾夫，後向きステップ再付着領域の熱伝達の時空間的非定常特性，日本機 械学会論文集 B 編, Vol. 54, No. 504 (1988), pp. 2114-2120.

Koide, Y., Sasaki, R., Kameya, Y. and Motosuke, M., A burst wave-induced plasma actuator for controlling separated flow over a backward-facing step at low Reynolds numbers, Experimental Thermal and Fluid Science, Vol. 66 (2015), pp.72-78.

Kondoh, T., Nagano, Y. and Tsuji, T., Computational study of laminar heat transfer downstream of a backward-facing step, International Journal of Heat and Mass Transfer, Vol. 36, No. 3 (1993), pp. 577-591.

Le, H., Moin, P. and Kim, J., Direct numerical simulation of turbulent flow over a backward-facing step, Journal of Fluid Mechanics, Vol. 330 (1997), pp. 349-374.

小川洋平, 田村渥, 佐野正利, 二次元オフセット噴流の流動特性と熱伝達, 日本機械学会論文集, Vol. 81, No. 825 (2015) , DOI:10.1299/transjsme.15-00066.

佐野正利，櫻庭健一郎，後向きステップを有するチャネル乱流の受動的制御（伝熱特性と圧力損失特性），日本 機械学会論文集 B 編, Vol. 67, No. 659 (2001), pp. 1770-1777.

佐野正利，須藤輝美，遠藤慶亮，杉山勇気，鈴木進，プラズマアクチュエータによる後向きステップ流れの損失 低減，日本機械学会論文集 B 編, Vol.78, No.785 (2012), pp.49-59.

佐野正利, 鈴木一平, 傾斜した後向きステップを有するチャネル乱流に関する研究, 日本機械学会論文集 B 編, Vol. 75, No. 755 (2009), pp. 1395-1401.

椎原尚輝, 中村元, 山田俊輔, 円管内オリフィス下流における流れの再付着位置と熱伝達極大位置の関係, 日本機 
械学会論文集, Vol.82, No. 840 (2016), DOI:10.1299/transjsme.16-00067.

日本機械学会編，技術資料 管路・ダクトの流体抵抗(1979), pp. 37-50.

Tihon, J., Legrand, J. and Legentilhomme, P., Near-wall investigation of backward-facing step flows, Experiments in Fluids, Vo. 31 (2001), pp.484-493.

Tihon, J., Penkavova, V., Havlica, J. and Simcik, M., The transitional backward-facing step flow in a water channel with variable expansion geometry, Experimental Thermal and Fluid Science, Vol. 40 (2012), pp.112-125.

Vogel, J. C. and Eaton, J. K., Combined heat transfer and fluid dynamic measurements downstream of a backward-facing step, Transactions of the ASME, Journal of Heat Transfer, Vol. 107 (1985), pp. 922-929.

Xie, W. A. and Xi, G. N., Fluid flow and heat transfer characteristics of separation and reattachment flow over a backward-facing step, International Journal of Refrigeration, Vol. 74 (2017), pp. 177-189.

山田俊輔, 本阿弥眞治, 岡本圭太，新田貴志，元祐昌廣，石川 仁，低レイノルズ数域における後方ステップ流 れの制御に関する研究（安定性解析を利用した Synthetic jet による再付着流れの制御）, 日本機械学会論文集 B 編, Vol. 77, No. 775 (2011), pp. 680-688.

\section{References}

Armaly, B. F., Durst, F., Pereira, J. C. F. and Schonung, B., Experimental and theoretical investigation of backward-facing step flow, Journal of Fluid Mechanics, Vol. 127 (1983), pp. 473-496.

Chen, L., Asai, K., Nonomura, T., Xi, G. and Liu, T., A review of backward-facing step (BFS) flow mechanics, heat transfer and control, Thermal Science and Engineering Progress, Vol. 6 (2018), pp. 194-216.

Chen, Y. T., Nie, J. H., Armaly, B. F. and Hsieh, H. T., Turbulent separated convection flow adjacent to backward-facing step - effects of step height, International Journal of Heat and Mass Transfer, Vol. 49 (2006), pp. 3670-3680.

Chun, K. B. and Sung, H. J., Visualization of a locally-forced separated flow over a backward-facing step, Experiments in Fluids, Vol. 25 (1998), pp.133-142.

Eaton, J. K. and Johnston, J. P., A review of research on subsonic turbulent flow reattachment, AIAA JORNAL, Vol. 19. No. 9 (1981), pp.1093-1099.

Honami, S., Recent advances in technology for flow control based on development of actuator induced aerodynamics, Transactions of the Japan Society of Mechanical Engineers, Series B, Vol.79, No.808 (2013), pp.2670-2678 (in Japanese).

Kawamura, T., Tanaka, S., Kumada, M. and Mabuchi, I., Time and spatial unsteady characteristics of heat transfer at the reattachment region of a backward-facing step, Transactions of the Japan Society of Mechanical Engineers, Series B, Vol.54, No.504 (1988), pp.2114-2119 (in Japanese).

Koide, Y., Sasaki, R., Kameya, Y. and Motosuke, M., A burst wave-induced plasma actuator for controlling separated flow over a backward-facing step at low Reynolds numbers, Experimental Thermal and Fluid Science, Vol. 66 (2015), pp.72-78.

Kondoh, T., Nagano, Y. and Tsuji, T., Computational study of laminar heat transfer downstream of a backward-facing step, International Journal of Heat and Mass Transfer, Vol. 36, No. 3 (1993), pp. 577-591.

Le, H., Moin, P. and Kim, J., Direct numerical simulation of turbulent flow over a backward-facing step, Journal of Fluid Mechanics, Vol. 330 (1997), pp. 349-374.

Ogawa, Y., Tamura, A. and Sano, M., Characteristics of fluid flow and heat transfer of two-dimensional offset jet, Transactions of the JSME (in Japanese), Vol. 81, No. 825 (2015), DOI:10.1299/transjsme.15-00066.

Sano, M. and Sakuraba, K., Passive control of turbulent channel flow over a backward-facing step, Transactions of the Japan Society of Mechanical Engineers, Series B, Vol. 67, No. 659 (2001), pp.1770-1777 (in Japanese).

Sano, M., Sudo, T., Endo, K., Sugiyama, Y. and Suzuki, S., Reduction of pressure loss in backward-facing step flow with plasma actuator, Transactions of the Japan Society of Mechanical Engineers, Series B, Vol.78, No.785 (2012), pp.49-59 (in Japanese).

Sano, M. and Suzuki, I., Study on turbulent channel flow over an inclined backward-facing step, Transactions of the Japan Society of Mechanical Engineers, Series B, Vol. 75, No. 755 (2012), pp. 1395-1401 (in Japanese).

Shiibara, N., Nakamura, H. and Yamada, S., Relation between the positions of flow reattachment and maximum heat transfer at downstream of an orifice in a pipe, Transactions of the JSME (in Japanese), Vol. 82, No. 840 (2016), DOI:10.1299/transjsme.16-00067. 
The Japan Society of Mechanical Engineers ed., JSME Data Handbook: Hydraulic losses in pipes and ducts (1979), pp.37-50 (in Japanese).

Tihon, J., Legrand, J. and Legentihomme, P., Near-wall investigation of backward-facing step flows, Experiments in Fluids, Vo. 31 (2001), pp.484-493.

Tihon, J., Penkavova, V., Havlica, J. and Simcik, M., The transitional backward-facing step flow in a water channel with variable expansion geometry, Experimental Thermal and Fluid Science, Vol. 40 (2012), pp.112-125.

Vogel, J. C. and Eaton, J. K., Combined heat transfer and fluid dynamic measurements downstream of a backward-facing step, Transactions of the ASME, Journal of Heat Transfer, Vol. 107 (1985), pp. 922-929.

Xie, W. A. and Xi, G. N., Fluid flow and heat transfer characteristics of separation and reattachment flow over a backward-facing step, International Journal of Refrigeration, Vol. 74 (2017), pp. 177-189.

Yamada, S., Honami, S., Okamoto, K., Nitta, T., Motosuke, M. and Ishikawa, H., Control of backward-facing step flow in low Reynolds number (Reattachment flow control by synthetic jet using stability analysis), Transactions of the Japan Society of Mechanical Engineers, Series B, Vol.77, No.775 (2011), pp.680-688 (in Japanese). 